\title{
A cartographic cum site-effectuated review of greater Shillong region of northeast
}

\section{India}

Rajib Biswas ${ }^{1 *}$, S. Boruah ${ }^{2}$

1. Applied Geophysical Lab, Department of Physics, Tezpur University, Assam784028, India

2. Geoscience Division,CSIR-NEIST, Jorhat, Assam, India

Corresponding author:rajib@tezu.ernet.in

\begin{abstract}
The cartographic cum site-effectuated view of Shillong region of northeast India is presented here. Starting from the existing tectonics, the prevalent geological settings of the study area is comprehensively delineated. The seismic prone area is further overviewed in the context of site effects with accompaniment of available borehole information. The resonance frequency estimates form ambient noise survey along with receiver functions are outlined which implicates a heterogeneous subsurface. This further helps in segregating the region into two compelling profiles, thereby enabling us to get a deeper insight in the probable subsurface as well as heterogeneity. Eventually, the influence of topography over strata was also highlighted and interpreted as well.
\end{abstract}

Keywords: cartography; seismic waves; subsurface; ambient noise survey

\section{Introduction:}

Northeastern Region (NER) of India and its adjoining area is one of the most complex tectonic provinces in the world. The geographical boundary with latitude: $22^{0}$ $30^{\circ}$ and longitude: $89^{\circ}-98^{\circ}$ covers considerable portion of NER, India. Plate boundary zone and the intraplate area are the main components of NER, India [1]. The intraplate 
part of the region comprises the Shillong Plateau, Mikir Hills, the Assam Valley and Tripura folded belt jawed between the two tectonic arcs, the Himalyan arc to the north and the Burmese arc to the east [2]. All these tectonic features with its complicated geotectonic setup, as shown in Figure 1 allow NER, India to be seismically very active. As a manifest of this statement, the region experiences smaller to moderate magnitude earthquakes that release sizable energy daily. During the last $110+$ years, the region had remained the witness to 20 large $(M \geq 7.0)$ and two great earthquakes of June 12,1897 [3] and August 15, 1950 [4-6]. These two great earthquakes have caused extensive destructions in the region killing more than $3 \mathrm{~K}$ lives with a loss of $\$ 30$ million [7]. The region lies in the seismic zone $\mathrm{V}$ of India [8] that is considered as the maximum rating zone in the National Seismic Zoning map of India. There are several tectonic faults and lineaments [9-10]. In the recent past, the region experienced earthquakes of greater than four in copious number. The frequent occurrence of such type of events makes this region a very interesting one; so far seismic investigations are concerned. Consequently, this region has become the center point of many seismological studies. Pertaining to this, there has been a lot of rise in the no. of seismic network/stations operated by different organizations since 1982. To name a few, India Meteorological Department (IMD)-Shillong, the North-East Institute of Science and Technology-Jorhat (NEIST-J) (formerly Regional Research Laboratory), the National Geophysical Research Institute, Hyderabad (NGRI-H) and several Universities established analog networks. All these stations, which were previously analog, are upgraded to broadband digital stations, aided by Global Positioning System synchronized time (GPS), since 2001. The active seismotectonics of the region has been subject to several studies $[11-14,1,6]$. Apart 
from the above studies, Shillong Plateau of northeast India also drew attention of several researchers because of its unique geological structure and intense seismo-tectonic activity. The area of the present study is actually embedded in the Shillong Plateau. Keeping all these in view, we present here a cartographic cum site-effectuated review of this seismically active area. Accordingly, the tectonic settings of the Shillong Plateau are initially overviewed in general. It is then followed by seismicity and geological settings of Shillong City. Apart from this, we also highlight site effects from ambient noise and their implications in particular in this study.

\section{Tectonic Settings of Shillong Plateau}

The Shillong Plateau together with the Brahmaputra valley in the northeastern region (NER) of India lie between $25^{0} \mathrm{~N}$ to $26.5^{0} \mathrm{~N}$ in latitude and $89.5^{0} \mathrm{E}$ to $93.5^{0} \mathrm{E}$ in longitude. It is seismically one of the most active zones in the World. The tectonic settings of the Shillong Plateau and its adjoining area are portrayed in Figure 2. The Shillong Plateau is a part of Indian Shield that was uplifted during the Tertiary period [15] which is associated with several E-W, N-S, NE-SW and NW-SE oriented faults and lineaments [16]. The Shillong Plateau consists of crystalline rocks partly covered by gently dipping Tertiary and younger sediments [9]. Geomorphologically, the Shillong Plateau has been quite intriguing. It represents a flat high land of about 1.0-1.5 $\mathrm{km}$ average regional elevation limited in an area of about 100 x $300 \mathrm{sq} . \mathrm{km}$. The Shillong Plateau has an average elevation of about $1500 \mathrm{~m}$ and high-grade metamorphic basement rocks of Achaean age, which are overlain by the mildly deformed Protozoic shelf sediments [17]. In fact, the Shillong Plateau lies at the junction of the Himalayan orogeny on the three sides viz. north, east and NE. Basement rocks in Shillong Plateau 
[18] consists of gneisses and migmatites with enclaves of amphibolite and high grade super crystals which is overlain by Shillong group of rocks of Proterozoic metasediments with oldest member of this group being of Mesoproterozoic period (1530-1550 Ma) and several granite plutons of 885-480 Ma [19]. The Shillong Plateau is characterized by positive Bouguer and Isostasy anomalies which [20] interpreted it to be the existence of denser and thicker crust beneath the Shillong Plateau.

The major geotectonic structures associated with this region are: the Brahmaputra fault to the north, the E-W Dauki fault to the south and NE-SW Naga Thrust to the east. There are two major thrust faults in the Shillong Plateau, namely: the Dapsi Thrust and Barapani shear zone [21]. According to [9], the Shillong Plateau has been separated from the peninsular shield and moved to the east along the Dauki fault. The E-W trending Dauki fault separates the Shillong Plateau to the north and Bengal basin to the south. [6] suggested that the Dauki fault separates the ancient continental crust of the Indian shield from the Cretaceous ocean floor, the Bengal Basin. The Dauki fault was interpreted by [9] to be a strike-slip fault along which the Shillong Plateau has translated eastward relative to the Indian shield by at least $150-300 \mathrm{~km}$. This observation is complemented by another study [22], based on satellite imagery that Dauki fault could be traced for about $300 \mathrm{~km}$ and different type of tectonics could be recognized along this fault than what it was earlier, while [17] interprets Dauki fault as nearly horizontal northwards beneath the Shillong Plateau at an estimated depth of 15 to $20 \mathrm{~km}$. Thus, this fault extends up to at least the northern edge of the Rajmahal Hills. As per [23], the Shillong Plateau is believed to possess a thrust plane beneath it. This plane, of late, is enduring southward thrusting along Dauki fault. This behavior is opposite to the axiom 
of vertical tectonism [24]. Two earthquakes near the eastern end of the Dauki fault were analyzed by [25] who determined thrust solutions for both on gently north dipping planes. [25], however, interprets these as strike-slip earthquakes and associates them with the Sylhet lineament. Also, [6] opined that the earthquake of February 6, 1988 $\left(m_{b}=5.8\right)$ occurred close to the Dauki fault on the southern edge of the Shillong Plateau. Also the seismicity of the Shillong Plateau is mostly confined to upper crust up to the depth of $25 \mathrm{~km}$.

Figure 1 also highlights the fault plane solutions corresponding to some major earthquakes occurring in the northeast region of India. The shown fault planes seem to be attuned with the accessible boundary faults. For instance, the north dipping Dapsi thrust and the south dipping Brahmaputra river fault can be cited as one of them. In addition to that, we can see a mixture of strike slip and normal faulting. In such cases, the Sylhet fault towards Bengal basin can be referred to. In addition, the other fault plane solutions as shown in Figure 1 with year of occurrences annotated bear striking congruence with the prevalent faults and lineaments; thus implicating a high seismo-tectonic activity pertinent to this region.

To the north along the Brahmaputra River valley, the main east-west trending northern boundary of the Shillong Plateau is Brahmaputra fault [26]. The Dapsi Thrust is a north dipping seismogenic fault. However, high microearthquake activities along the WNW-ESE trending Dapsi reverse fault (Tura area) indicate concentration of high stress in that area. To the west, the Dhubri fault identifies the western margin of the Plateau. The major tectonic features surrounding Shillong is displayed in Figure 2. 
As mentioned earlier, the study area falls in one of the most seismically active regions, i.e; Shillong Plateau. It is noteworthy that several large earthquakes (M>7.0) have occurred in the NER, India and its eastern extension and the northern Bengal Basin in the last $\sim 110+$ years. Of the several earthquakes, four have occurred in the Shillong Plateau area, one of them is the $\mathrm{M}_{\mathrm{W}} 8.1$ earthquake of June 12, 1897 [27]. Apart from 1897 earthquake, three large earthquakes $M>7.0$ occurred in this zone. As for instance, we could mention the September 9, 1923 earthquake of M 7.1 that befell at the western edge of the SP. The fault responsible was the Dauki fault. Again, there was occurrence of M 7.1 of July 2, 1930 earthquake at western margin of SP (mostly cited as Dhubri earthquake), as triggered by Dhubri fault. Additionally, as depicted in Fig.3, we could refer to the October 23, 1943 earthquake of M 7.2 occurring at the eastern boundary of Shillong Plateau. The Great Shillong earthquake of 1897 highlighted the seismotectonic activity of the area. A south dipping hidden fault at the northern boundary of the Shillong Plateau, parallel to the E-W segment of the Brahmaputra River, was proposed as the Oldham fault [27]. The focal mechanism solution of a close earthquake suggested thrust faulting with a significant component of strike slip motion. The location of the $110 \mathrm{~km}$ long, south dipping Oldham fault responsible for the great 1897 earthquake rupture beneath the Shillong Plateau remains a matter of disagreement [28]. The presence of major reverse faults on both sides of the Shillong Plateau supports the interpretation in terms of a giant 'pop-up' structure [27]. The hypocenters of earthquakes in the Plateau regions are mostly confined within $50 \mathrm{~km}$. It is observed that in Shillong Plateau, $80 \%$ of the events are occurring within depth range of $10-40 \mathrm{~km}$ and $20 \%$ of the events are 
occurring within depth range of 40-60 km which enables one to demarcate the most active seismogenic zone [see Figure 3].

Several researchers carried out extensive studies regarding seismicity of this region. [29] studied the seismicity of this region and the part of the eastern Himalaya, based on high quality seismic data recorded by the local stations in 1982-1990. The seismic activity is notably high in the depth zone of $10-20 \mathrm{~km}$ below the Shillong Plateau. Another study by [30] mapped the crustal discontinuities beneath Shillong Plateau utilizing reflected phases of $\mathrm{P}$ and $\mathrm{S}$ waves. Based on baseline geodetic GPS data from 1997 and 2003 to 2006, [31] showed that within the framework of N-S convergence between Eurasia and India $\left(16 \mathrm{~mm} \mathrm{yr}^{-1}\right)$, the present day deformation is statistically insignificant within the SP and very negligible deformation to north of the Shillong Plateau and south of the Arunachal Himalaya in the Brahmaputra valley. This also implies that the Dauki fault and the Oldham fault are locked below the Shillong Plateau at present and not undergoing any interseismic deformation. It may be mentioned about a significant earthquake of June 1, 1969 with a magnitude of 5.0 having an epicentral distance of $20 \mathrm{~km}$ from Shillong [13], which was felt rigorously. According to [13], since 1970, there has been gradual decrease in P-wave velocity yielding a speculation that the region is experiencing a dilatancy stress, precursory to a large earthquake. According to [17], the Shillong Plateau shows a pertinent seismic activity with an average of more than ten small magnitude earthquakes per day which is again enriched by instrumental records of more than 30 large earthquakes. With the advent of digital seismic networks set up by NEIST (Formerly known as RRL) Network, IMD, there has been a tremendous improvement in the recording of microtremors. 
Accordingly, the seismicity in the Shillong area can be presumed to be moderate. On a closer look, Borapani Shear Zone may be perceived to be the limiting region of this moderate seismicity. Very recently, the no. of felt tremors with their epicenters located in proximal areas of Shillong City has been rising considerably. All these complex tectonic settings contribute towards making Shillong region a seismically vulnerable zone.

\section{Geological settings of Shillong city}

Shillong is one of the heritage cities of Northeast India. It is the capital of Meghalaya State. It has an altitude of 1496 meters above sea level, with an average population of 5 lacs. The Umiam Gorge bound it to the North whereas Diengiel Hills and Assam valley flank this region in the Northwest and Northeast direction, respectively. Precisely, the basement of Shillong Plateau is of Archaean gneissic. Sediment fillings along its southern margin belonging to late Cretaceous-tertiary era also exist [32-38]. Apart from this, the Brahmaputra graben treads along north of SP whereas Dauki Fault goes along south of SP [37-38]. Existence of several faults in and around Shillong city having major trends along NE-SW, N-S and E-W directions [32] makes the city more vulnerable so far earthquake hazard is concerned. During these recent years, urbanization in Shillong has grown up tremendously, which poses a great threat in the context of Seismic Hazard keeping in view of its active seismotectonics. The area studied is occupied by a group of epimetamorphic rocks with basic intrusive which are locally known as Khasi Greenstone as displayed in Figure 4. The rocks comprise epimetamorphic argillaceous and arenaceous sequences. The argillites 
interbedded with arenites, are exposed mainly in the central and southern part and form high ridges, such as Shillong and Laitkor peaks.

The argillites include reddish brown, pinkish to purple colored phyllites and quartz schists and show well preserved foliation and schistocity. The arenites comprise of pinkish white, light grey to buff colored massive and coarse quartzites, interbedded with thin partings of siltstone and phyllite, contain preserved sedimentary structures. The areas to the north and west of the Phudmawri Quartzite are highly oxidized and have given rise to the thick laterite cover. Evidences of breciation within the Quartzites have been seen near Mawpat and southeast of Laitkor in a nala section [33-34]. Thick beds of intraformational conglomerate interbedded with quartzites and quartz schists are seen exposed southeast of Mawlai, the plateau between Laitkor peak and Shillong town. The quartzites, exposed along the scrap face are compact and massive and show striated surfaces. The basic intrusive occur as linear concordant bodies and usually show sharp contact with the country rocks [35-40].

The rocks of the Shillong group show a persistent NE-SW trend with minor swings and dip towards SE at an angle cleavage and schistocity also have a persistent north elasticity strike with minor variation. More than one set of folding has led to complex fold geometry. The Khasi Greenstone [31] is a group of basic intrusives in the form of linear to curvilinear occurring as concordant and discordant bodies within the Shillong group of Rocks and suffered metamorphism [38] . These kinds of rocks are highly weathered and the degree of weathering is found to be more in topographic depressions than in other areas. The metabasic rocks are more prone to weathering than 
quartzite rocks. In low-lying areas like Laban, Richa Colony and Rylbong etc., valley fill sediments are also prominent.

\section{Lithologs in \& around Shillong City}

In conformity with local geology of Shillong, it was possible to acquire an appreciable amount of borehole information of fourteen particular sites in \& around Shillong City. These data sets were procured from government departments like Central Ground Water Board and Public Health Engineering Department exclusively located in Shillong City. So far, the litholog information is concerned, only fourteen sites were available. The stratigraphic information covers up to a depth of 100 meters in most cases. Barring some of the sites, deep borehole data beyond 250 meters of depth were also prominent. The litholog information of ten borehole sites are incorporated as they mainly fall in the urban part of Shillong City and in the immediate neighborhood of ambient noise location points as illustrated in Figure 4.

Additionally, the site effectuated view of greater Shillong region is tried to understand from the resonance frequency estimations through $\mathrm{H} / \mathrm{V}$ ratio from ambient noise survey [For details, see [43]]. Figure 5 illustrates the estimates of resonance frequency as well as mapping of it spanning the entire Shillong City. Figure 5a and 5b exemplify the estimation of resonance frequency corresponding to two sites whereas $5 \mathrm{c}$ depicts the contour plot of resonance frequency. We see a considerable variation of resonance frequency throughout the area under study. In order to emphasize the heterogeneous distribution of resonance frequencies, we plot two profiles $A B$ and $C D$ in close proximity of the borehole locations. 
Further, we include more results oriented towards site effects. A temporary network of stations was installed in three sites of Shillong region, which were in the immediate neighborhood of boreholes. As for illustration, Figure 6 highlights those results. Figure 6a shows the locations of the station and Figures 6 (b)-(d) represent the findings as computed from receiver function technique corresponding to three stations IIG, SETUK and NEHU [for more details, see [44]]. The results pertaining to site response at the three investigation sites through this receiver function technique emerge out to be similar in the range of 4-8 Hz. They tally with the estimates of fundamental frequencies estimated through ambient noise recordings at these same sites. These findings implicate changes in geology and soil conditions prevailing in the region.

Pertaining to ten sites where borehole-drilling data are available, the underneath subsurface structure is constructed. However, it is clarified that the borehole drilling were executed with the sole aim of exploring/tapping ground water. The highest depth up to which geological information is available is found to be more than 250 meters.

Further, as stated earlier, two profiles $\mathrm{AB}$ and $\mathrm{CD}$ are defined inclusive of the borehole sites. Corresponding to these two sections, the topographical profile is plotted in Figure 7 that shows an undulating topographical variation. So far the distribution of resonance frequencies across these two profiles are concerned, it appears to be totally heterogeneous; accompanied by a declining elevation pattern. In case of $\mathrm{AB}$ cross section, the variation of resonance frequencies follows some pattern. As revealed in Figure 5c along with Figure 7; the higher resonance frequencies are somewhat confined to sites with higher elevation; while; the less elevated regions seem to yield lower 
frequency estimates. However, in case of CD cross section, the pattern appears to be random; ruling out any correlation between resonance frequencies with elevation. As such; without a greater coverage of area and adequate survey points, it would be too ambitious to draw out a fine correlation between resonance frequency of estimates and altitudes.

\section{Discussions and inference}

Shillong and its neighboring region have always grabbed the attention of geologists, seismologists for its interesting geological footprint. So much diversity lies in this small area that it is adequate to result in unique seismic signature, which is only characteristic to itself. Some researchers extensively studied about the path and site characteristics prevailing in this region. As for example, the attenuation characteristics existing in Shillong and neighboring region were comprehensively delineated by [35-36]. They made use of micro earthquake spectra where they found disparities in signal content in very nearby stations corresponding to identical events, which eventually led to the strong establishment of site effects; thus implying varying local lithology existing in and around Shillong. Meanwhile, Biswas et al [37] utilized modified form of Nakamura method to formulate suitable relationship of resonant frequency with depth as well as overburden thickness. As per [37-38], the subsurface suffers from considerable heterogeneity. The study was further accentuated by Biswas and Boruah, 2015 [39] who executed a nonlinear earthquake site response analysis. From the recorded accelerograms, they estimated fundamental frequencies. The frequency estimates seemed to comply with the passive seismic noise recordings; thus giving more foresight in the heterogeneous stratification as observed in the Shillong region. Biswas and 
Boruah [44] combined noise data with earthquake recordings where they found identical variation of resonant frequencies. As observed, the resonant frequency estimates from ambient noise are quite a match with receiver function corresponding to earthquake recordings in the range of 3 to 7 . In another study by [45], H/V ellipticity intermingled with SPAC analysis resulted in the subsurface profiles with varying shear wave velocities. In the same note, there was compelling evidence of varying shear wave velocity profiles prevalent in Shillong region, which also advocated the existence of low velocity zones at some pocket areas [46]. In another recent study [47], there is indication of the existence of stiff soil and rocks at different depths whereas resonant frequency; thus revealing a vulnerability rate of $60 \%$. Accordingly, the topographical profile as shown in Figure 7 bears much significance. As seen in the two demarcated profiles, the topographical undulations bear quite resemblance with the heterogeneous stratifications as observed in the previous literatures.

\section{Conclusion:}

Conclusively, the cartographic and site effectuated analysis have been presented. There emerges to be active seismotectonics in the study region. Starting from the existing tectonics, the prevalent geological settings of the study area is comprehensively delineated. Along with this, we analyze the site effects pertaining to resonance frequency estimates. We further complement it with receiver function results. The seismic prone area is further overviewed in the context of available borehole information, which helps in segregating the region under study into two compelling profiles, thereby helping to get a deeper insight in the probable subsurface as well as heterogeneity in conformity with the published literatures. Eventually, the influence of 
topography over strata was also highlighted and interpreted, as well. There is ample evidence of topography over strata present in this seismically active area. The results are an indication of highly vulnerable index for the study region. 


\section{References:}

1. Nandy D.R. (2001). Geodynamics of Northeastern India and the adjoining region. Calcutta: ACB publications, 2001. 209.

2. Curry, JR, Emmel FJ, Moore DG, et al. Structure tectonics and geological history of the northeastern Indian Ocean. In: The Ocean Basins and Margins, vol. VI. The Indian Ocean, A.E.M. Nairn and F.G. Stehli (eds) 1982; VI :399-450.

3. Oldham RD. Report on the great earthquake of the 12th June 1897. Mem. Geol. Sur. India, 1899; 29: 1-379.

4. Poddar MC. Preliminary report of the Assam earthquake of 15th August 1950. Geol. Surv. India Bull. Ser., 1950; B (2), 1-40.

5. Richter CF. Elementary Seismology. San Francisco, WH Freeman \& Co. 1958; pp. 768.

6. Chen WP and Molnar P. Source parameters of earthquakes and Intraplate deformation beneath the Shillong Plateau and the Northern Indoburman Ranges. J. Geophys. Res. 1990; 95, 12,527-12,552.

7. Tillottson E. The great Assam earthquake of 1950, the completion of papers on the Assam Earthquake of August 15, 1950, Compiled by M.B. Ramachandra Rao, 1953; 94-96.

8. BMTPC. Vulnerability atlas- 2nd edn. peer group MoH \& UPA; seismic zones of India IS: 1983-2002, BIS, GOI, Seismotectonic atlas of India and its environs, 2003; GSI, GOI.

9. Evans P. Tectonic framework of Assam. Jour. Geol. Soc. India, 1964; 5, 80-96.

10. Kumar MR, Raju PS, Devi EU, et al. Crustal structure variations in northeast India from converted phases. Geophys. Res. Lett., 2004; 31, 1-4.

11. Tapponnier P, Peltzer G, Le Dian AY, et al. Propagating extrusion tectonics in Asia: New insights from simple experiments with plasticine. Geology 1982; 10, 611-616.

12. Le Dain AY, Tapponnier P and Molnar P. Active faulting and tectonics of Burma and surrounding regions. J. Geophys. Res. 1984; 89, 453-472. 
13. Gupta, HK and Singh HN. (1986). Seismicity of northeast India region. Part II: Earthquake swarm precursory to moderate magnitude to great earthquakes. J. Geol. Soc. India 1986; 28, 367-406.

14. Gowd TN, Sriram R, SV and Chary KB. Seismotectonics of northeastern India. Curr. Sci., 1998; 74, 75-80.

15. Rao, NP and Kumar MR. Uplift and tectonics of the Shillong Plateau, Northeast India. Jour. Phys. Earth, 1997; 45, 167-176.

16. Bhattacharya PM, Mazumdar RK and Kayal JR. Fractal dimension and b-value mapping in northeast India. Curr. Sci., 2002; 82(12), 1486-1491.

17. Khattri KN, Chander S, Mukhopadhyay S, et al. A model of active tectonics in the Shillong Massif region, Himalayanorogen and global tectonics, edited by A.K.Singh,New Delhi, Oxford \& IBH publishing Co. pvt. Ltd. 1992; 205-222.

18.Ghosh S, Fallick AE, Paul DK, et al. Geochemistry and origin of neoproterozic granitoids of Meghalaya, Northeast India: implication for linkage with amalgamation of Gondwana supercontinent. Gondwana Research 2005; 8, 421-432.

19. Mitra $S$ and Mitra $C$. Tectonic setting of the precambrians of the northeastern India, Meghalaya Plateau, and age of Shillong group of rocks. Geological Survey of India Special publication, 2001; 64, 653-658.

20. Verma KK and Mukhopadhyay M. An analysis of the gravity field in northeastern India. Tectonophysics 1977; 42, 283-317.

21. Kayal JR. Earthquake prediction in Northeast India- A review. Pure App. Geophys. 1991; 136, 297-313.

22. Das JD, Saraf AK and Jain AK. Fault tectonics of the Shillong Plateau and adjoining regions, northeast India using remote sensing data. Int. Jour. Remote Sensing $1995 ; 16(9), 1633-1646$.

24. Murthy MVN. Tectonic and mafic igneous activity in northeast India in relation to the upper mantle. Proc. $2^{\text {nd }}$ Symp. Upper Mantle Project, NGRI, Hyderabad, 1970; 287-304. 
25. Chandra U. Seismicity, earthquake mechanism and tectonics along the Himalayan mountain range and vicinity. Phys. Earth Planet. Int. 1978; 16, 109-131.

26. Dasgupta S and Nandy DR. Seismicity and tectonics of Meghalaya Plateau, Northeast India. VII Symposium on Earthquake Engineering, University of Roorkee, 1982; 1, 19-24.

27. Bilham R and England P. Plateau "pop-up" in the Great 1897 Assam earthquake. Nature 2001; 410, 806-809.

28. Rajendran CP, Rajendran K, Duarah BP, et al. (2004). Interpreting the style of faulting and paleoseismicity associated with the 1897 Shillong, northeast India, Earthquake: Implications for regional tectonism. Tectonics, 2004; 23, 1-12.

29. Baruah S, Duarah R and Yadav DK. Pattern of seismicity in Shillong Mikir plateau and the orientation of compressional axis, J. Geol. Soc. Ind. $1997 ; 49,533-538$.

30. Baruah S, Bora D and Biswas R. Estimation of crustal discontinuities from reflected seismic waves recorded at Shillong and Mikir Hills Plateau, Northeast India, Int. J. Earth Sciences 2010;

31. Jade S, Vijayan MSM, Gupta SS, et al. Effect of the M 9.3 Sumatra-Andaman islands earthquake of 26 December 2004 at several permanent and campaign GPS stations in the Indian continent, International Journal of Remote Sensing, 2007; 28, 3045-3054.

32. Rao JM and Purnachandra Rao GVS. Geology, Geochemistry and Palaeomagnetic study of Cretaceous Mafic Dykes of Shillong Plateau and Their Evolutionary History Indian Dykes: Geochemistry, Geophysics and Geomorphology, 2008, 589-607.

33. Sar SN (1973). An interim report on ground water exploration in the Greater Shillong area, Khasi Hills District, 1973; Meghalaya: Memo report, Central Ground Water Board

34. Kalita BC. Ground water prospects of Shillong Urban Aglomerate. Unpublished report. Central Ground Water Board, Meghalaya, 1998. 
35. Biswas R, Bora D, Baruah S, et al. The Effects of Attenuation and Site on the Spectra of Microearthquakes in the Shillong Region of Northeast India, Pure and App. Geophysics, 2013; 170(11), 1833-1848.

36. Biswas $\mathrm{R}$, Bora $\mathrm{D}$ and Baruah $\mathrm{S}$. Influence of attenuation and site on microearthquakes' spectra in Shillong region, of Northeast, India: A case study; Acta Geophysica, 2013; 61(4), 886-904.

37. Biswas R, Bora D and Baruah S. Mapping Sediment Thickness in Shillong City of Northeast India through Empirical Relationship, Journal of Earthquakes, Volume 2015, Article ID 572619

38. Biswas R., Baruah S and Baruah S, A Brief overview of site response estimation techniques, Italy, Mistral Services, 2014; ISBN: 978-88-98161-25-6.

39. Biswas $\mathrm{R}$ and Baruah $\mathrm{S}$. Shear wave velocity estimates through combined use of two passive techniques of a tectonically active area, Acta Geophysica, 2016; $(64 / 6)$

40. Biswas R, S. Boruah, Non-Linear Earthquake Site Response Analysis: A case study in Shillong City, IJEHRM, 2016; (3:4).

41. Devi N. and Sarma KP. Strain analysis and stratigraphic status of Nongkhya, Sumer and Mawmaram conglomerates of Shillong basin, Meghalaya, India J. Earth Syst. Sci., 2010; 119(2), 161-174.

42. Baruah S, Hazarika D, Gogoi NK, et al. The effects of attenuation and site on the spectra of micro earthquakes in the Jubilee Hill region of Hyderabad, India J. Earth Sys Sci. 2007; 116, 37-47.

43. Biswas R, Baruah S. Assessing site response through ambient noise measurements in a seismic prone area. Phys Astron Int J. 2019;3(2):72-80. DOI: 10.15406/paij.2019.03.00161

44. Biswas R, Bora N, Baruah S. Frequency dependent site response inferred from microtremors accompanied by ambient noise. Phys Astron Int J. 2018;2(4):273277. DOI: 10.15406/paij.2018.02.00098

45. R. Biswas, S. Baruah, Shear wave velocity estimates through combined use of two passive techniques of a tectonically active area, Acta Geophysica, 2016 (64/6) 
46. Biswas, R., S. Baruah, Nilutpal Bora, Assessing shear wave velocity profiles using multiple passive techniques of Shillong region of northeast India, Natural Hazards, December 94(3), 1024-1041, 2018.

47. Baruah, S., G. K. Baruah, et al. Seismic vulnerability assessment of earthquakeprone mega-city Shillong, India using geophysical mapping and remote sensing, Georisk: Assessment and Management of Risk for Engineered Systems and Geohazards, 2019, https://doi.org/10.1080/17499518.2019.1598560 


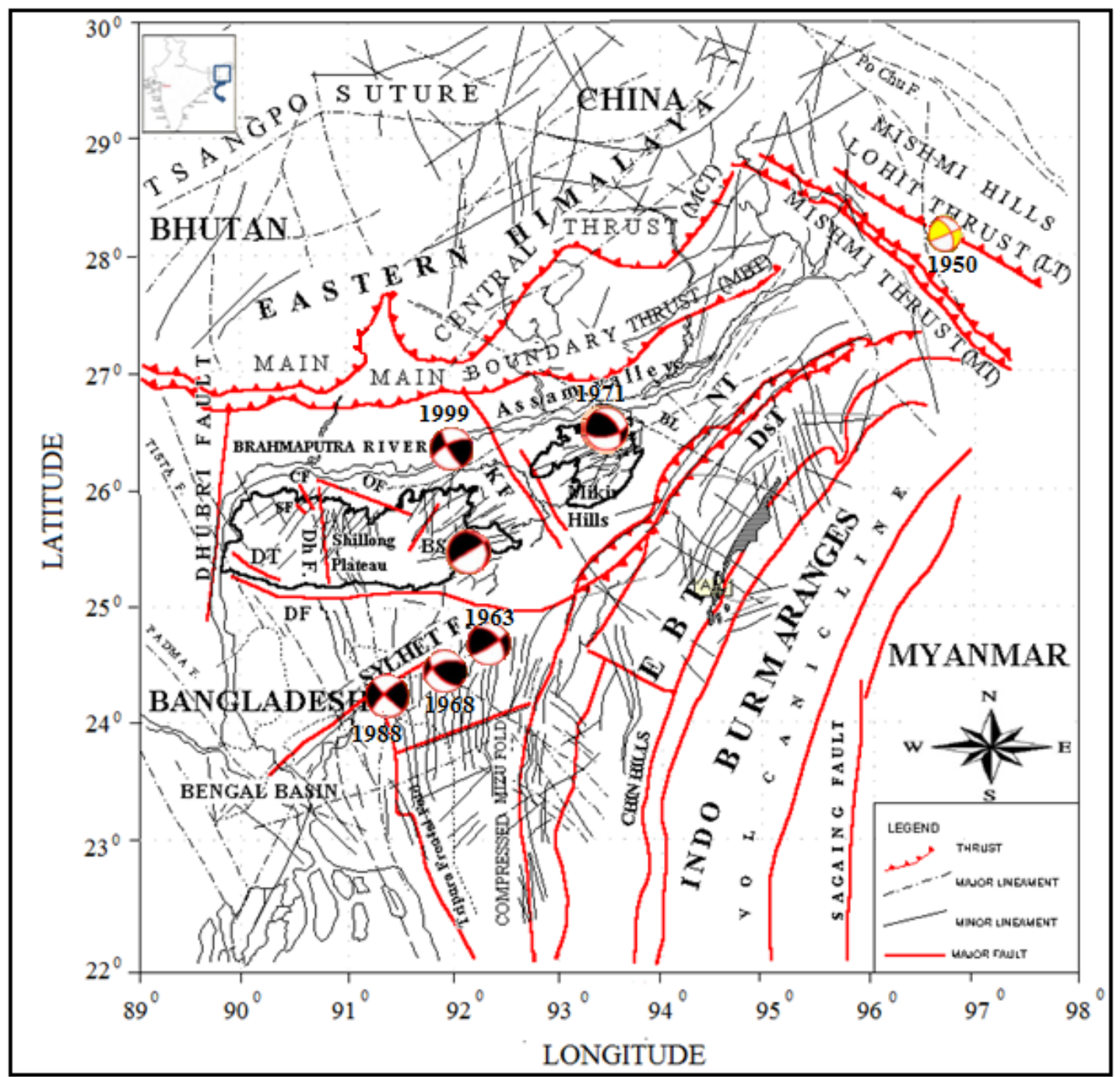

Figure 1 Tectonic settings of NER, India and surrounding regions. The major tectonic features in the region are indicated; MCT: Main Central Thrust, MBT: Main Boundary Thrust, DF : Dauki Fault, DT : Dapsi Thrust, Dh F :Dudhnoi Fault, OF: Oldham Fault, CF : Chedrang Fault, BS: Barapani Shear Zone, KF: Kopili Fault, NT : Naga Thrust, DsT :Disang Thrust and EBT: Eastern Boundary Thrust, BL: Bomdila Lineament. MT: Mishmi Thrust, LT: Lohit Thrust, SF: Sagain Fault. Inset: map of India indicating the NER, India. The conventional beach balls refer to the fault plane solutions of some major events (year of occurrence annotated) of NER, India; the dark and yellow area imply compression and open area dilatation (Modified After [42]). 

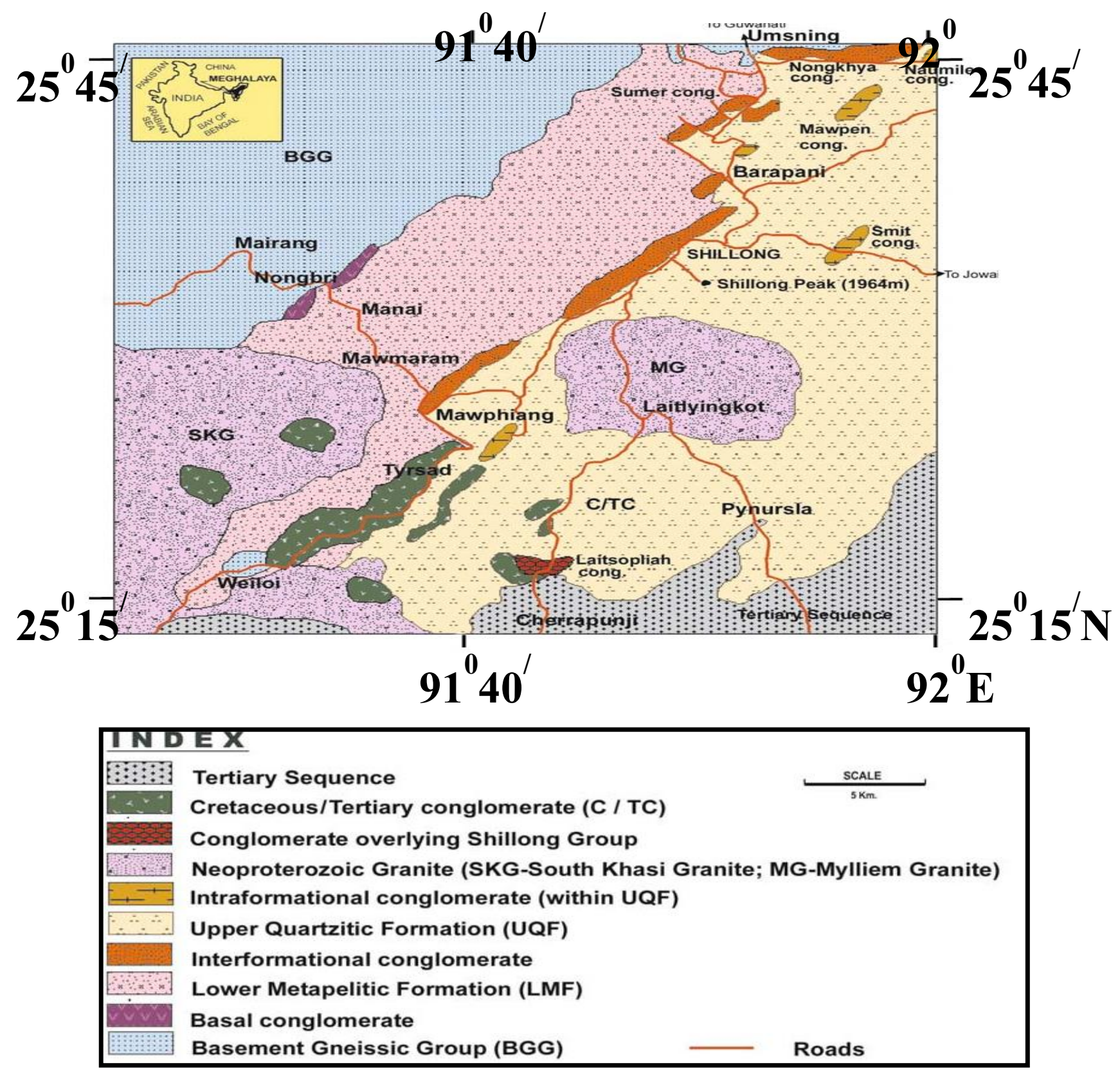

Figure 2 Geological settings in and around Shillong region (Modified After [41]) 


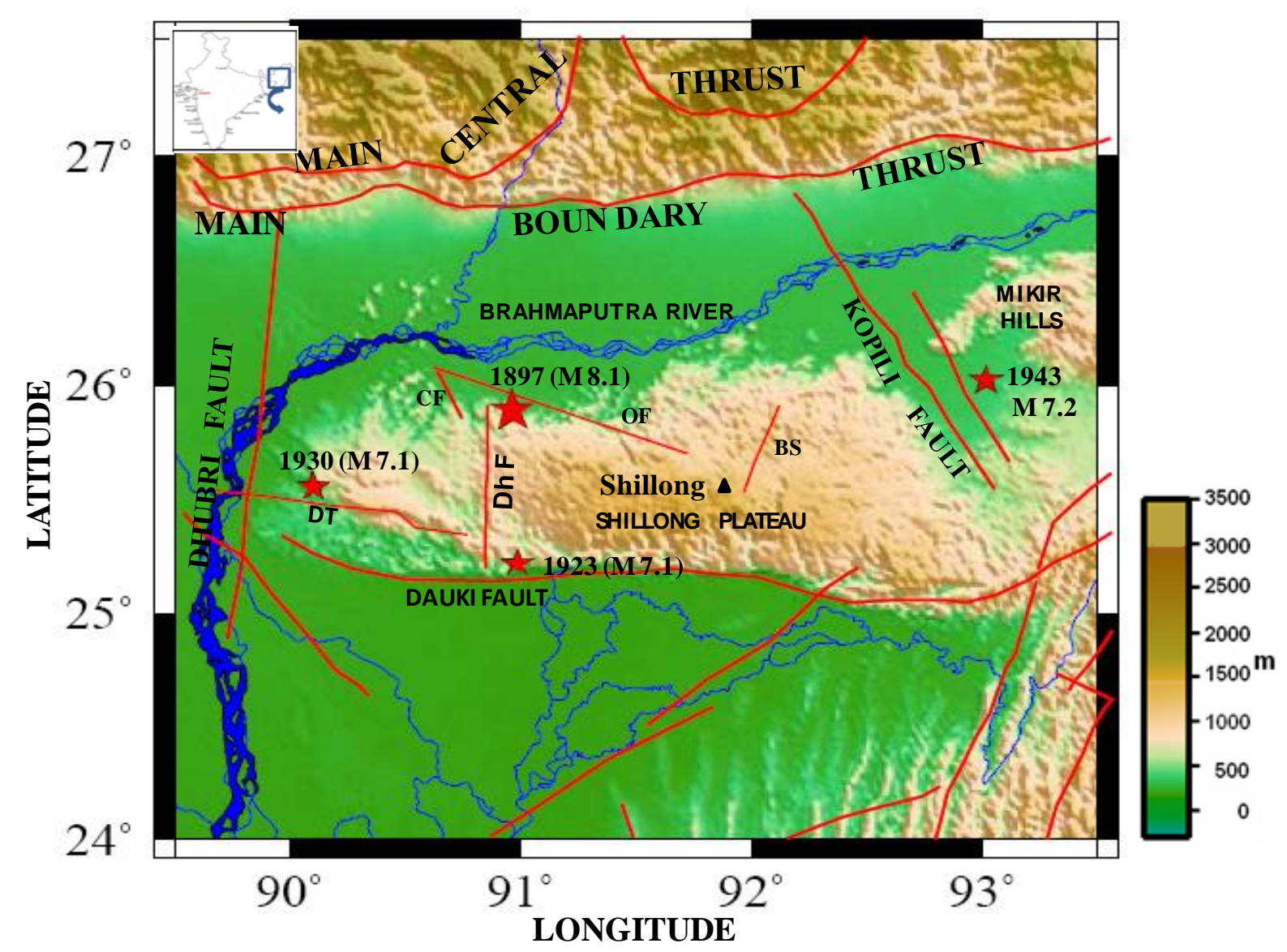

Figure 3 Tectonic settings around Shillong Plateau. The major tectonic features in the region are indicated; MCT: Main Central Thrust, MBT: Main Boundary Thrust, DF: Dauki Fault, DT: Dapsi Thrust, Dh F: Dudhnoi Fault, OF: Oldham Fault, CF: Chedrang Fault, BS: Barapani Shear Zone, KF: Kopili Fault. Red stars show the great and large earthquakes. Inset: map of India indicating the study region. Color bar represents elevation. The triangle represents Shillong City. 


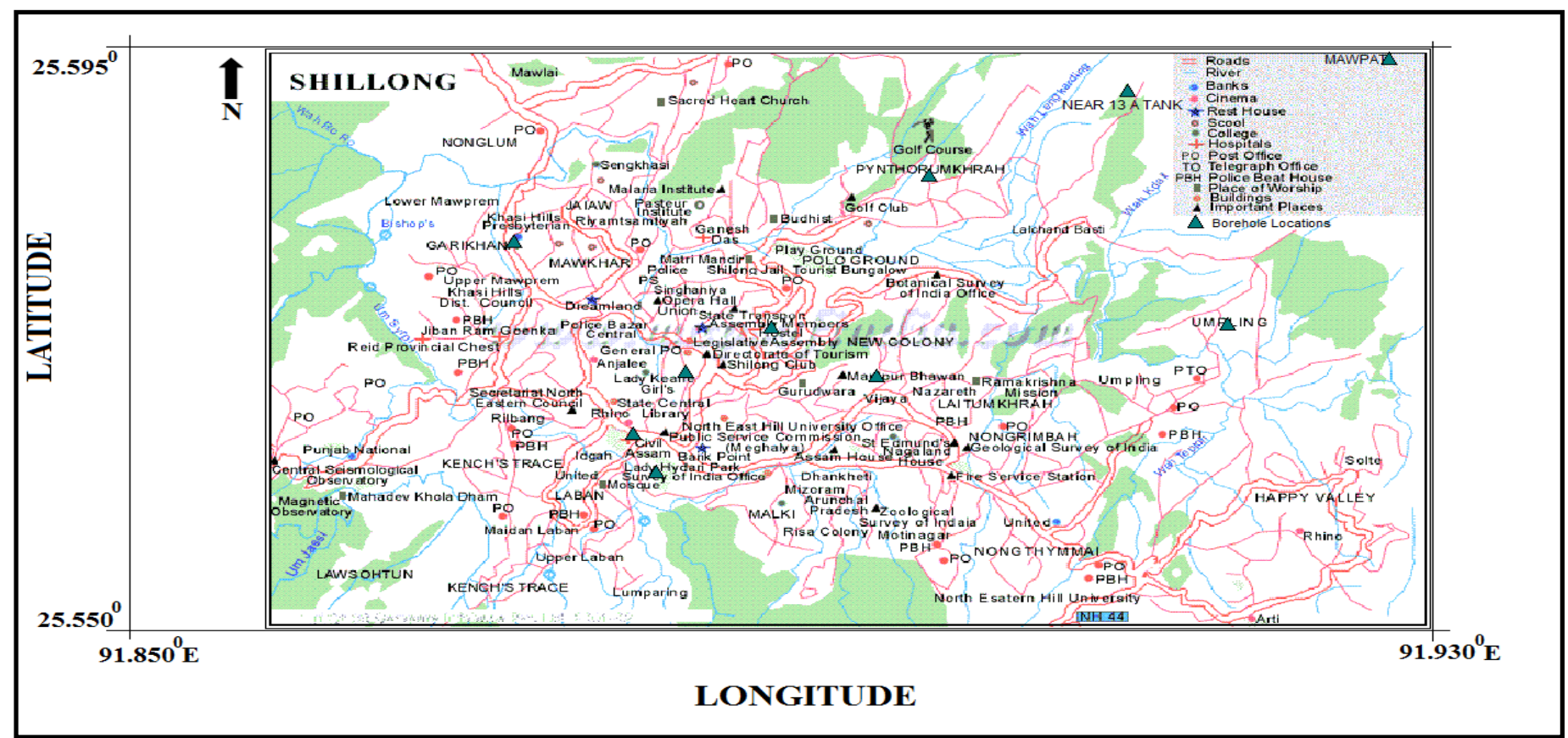

Figure 4 A greater view of Shillong City. 


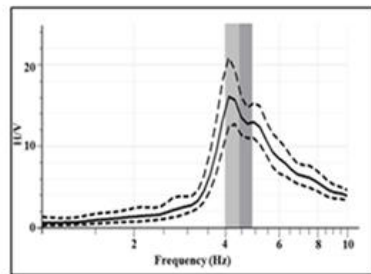

(a)

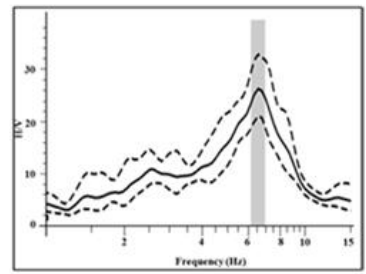

(b)

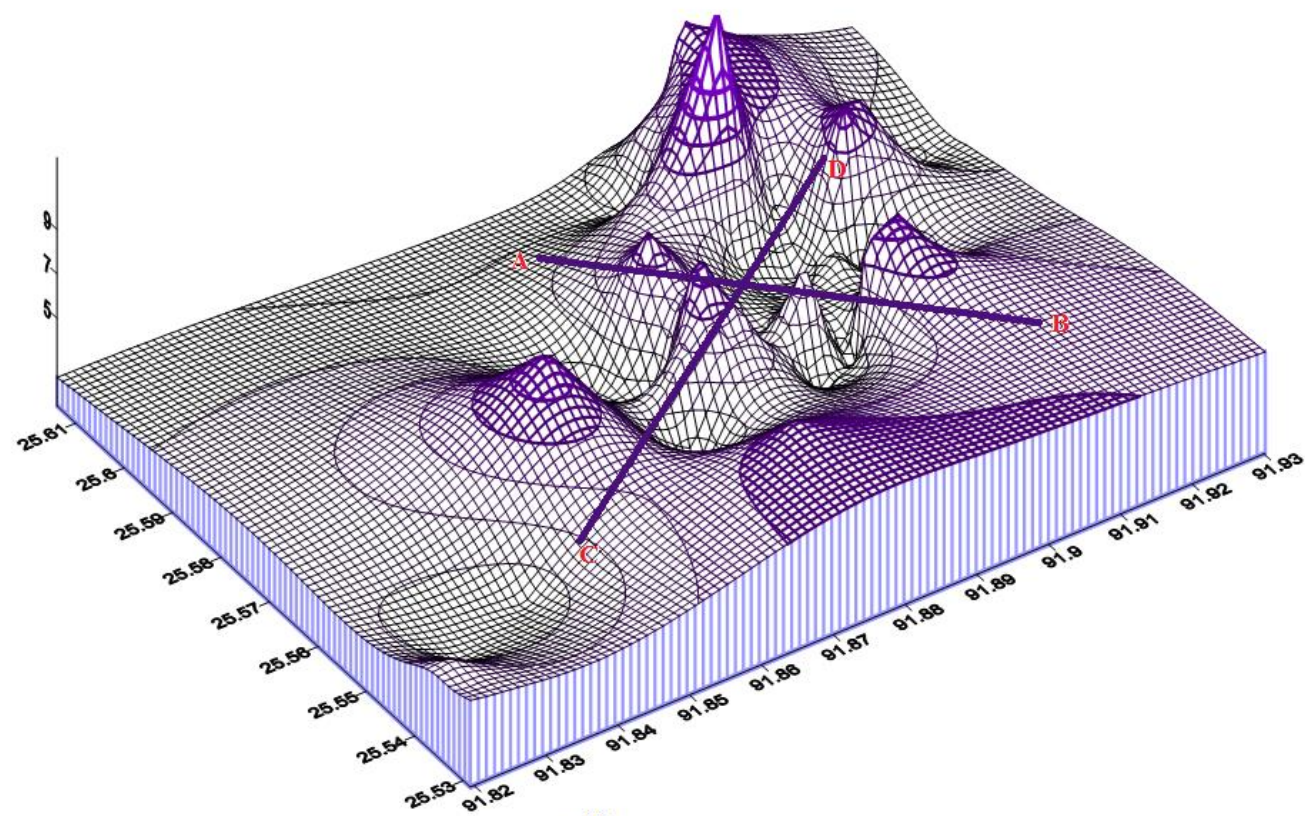

(c)

Figure 5 (a) \& (b) resonance frequency estimates and (c) Contour plot showing the distribution of resonance frequencies for the entire Shillong region. [Reproduced and modified from [43]] 


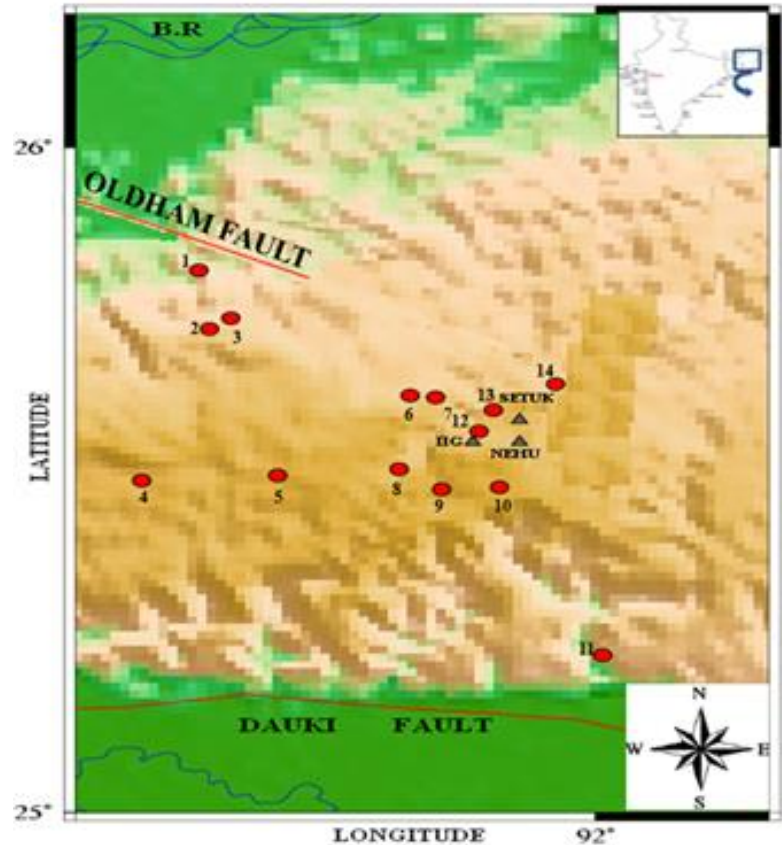

(a)

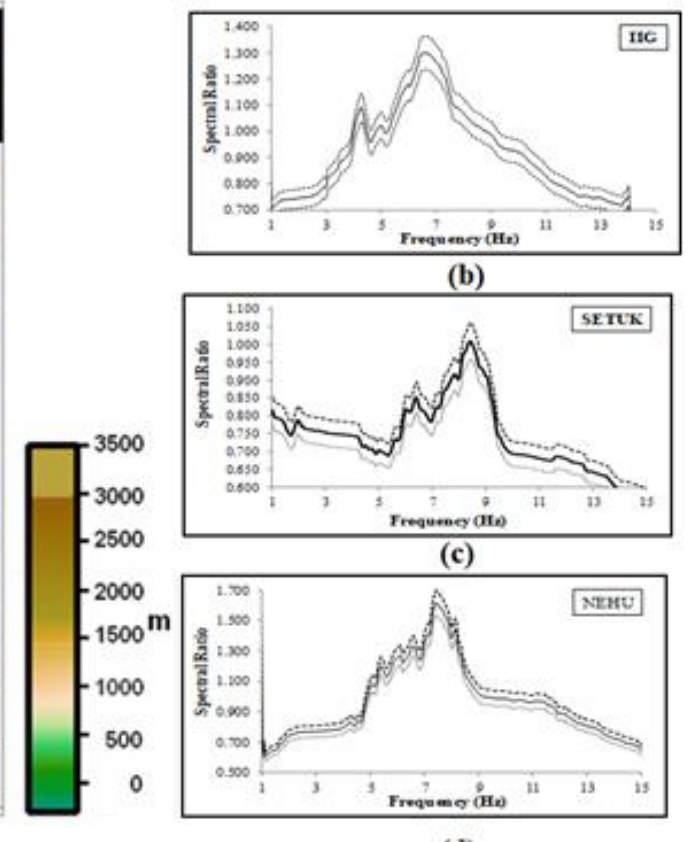

(d)

Figure 6. (a) Deployment of three temporary stations in Shillong region for site effect studies. HVSR estimates at the three temporary (b) IIG, (c) SETUK and (d) NEHU stations in Shillong region [Reproduced and modified from [44]] 


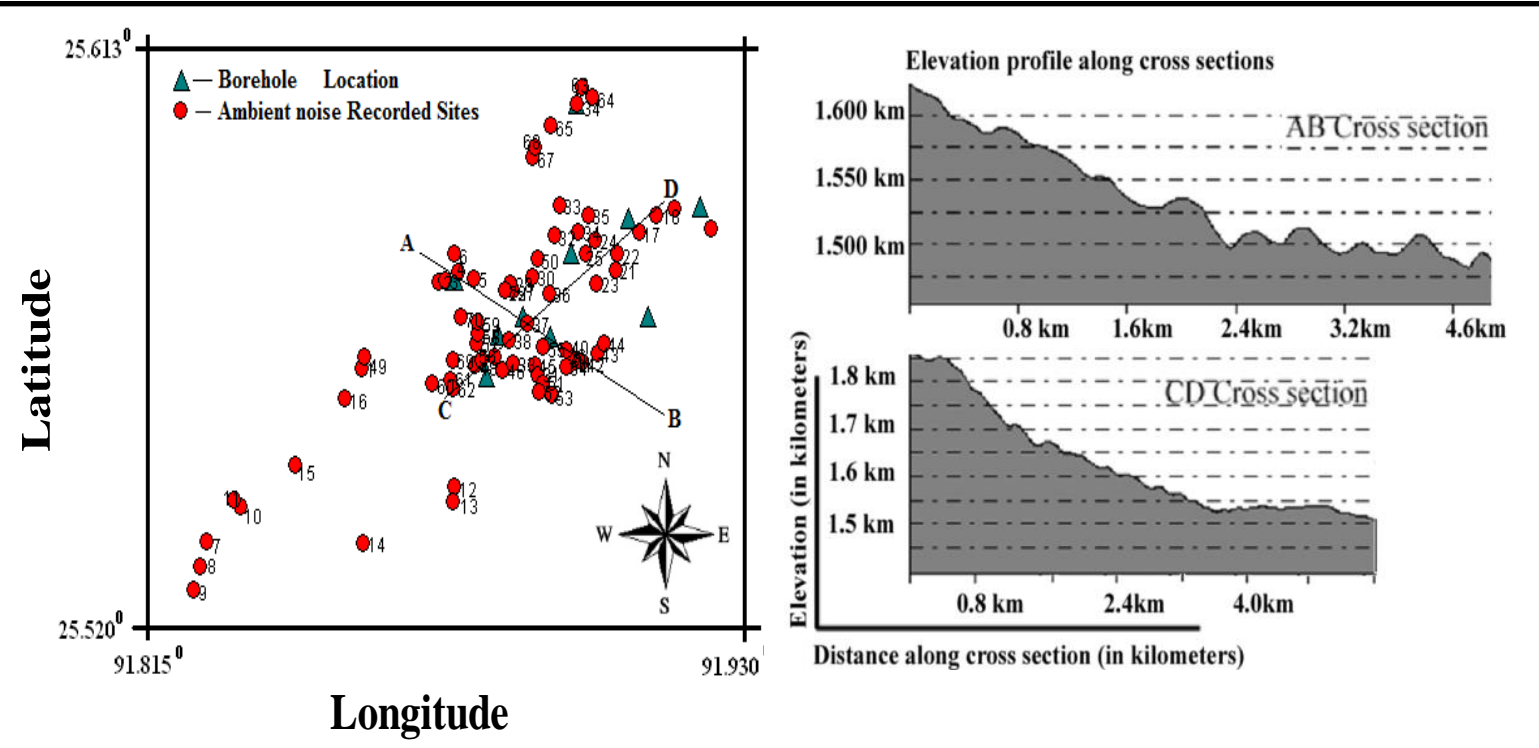

Figure 7. Towards left, the observed profiles $\mathrm{AB}$ and $\mathrm{CD}$ in conformity with the boreholes are shown. Corresponding Elevation profiles for these two sections $\mathrm{AB}$ and $\mathrm{CD}$ are given towards right (Modified after [43-45]). 